\title{
DEVELOPMENT OF LAW RELATING TO FACTORIES IN INDIA
}

\author{
MANJEET KUMAR SAHU, \\ National University of Study and Research in Law \\ (Ranchi, India)
}

The rapid growth of industrial town and factories has paved the way to develop our industrial legislation accordingly. The Government of India never expressed their interest in framing separate legislation vis-à-vis factories which resulted in implementation of the same statute which was enacted pre-independence. It was done by virtue of Art. 372 of the Constitution of India. However, the Constitutional Lawmakers created vacuum for the implementation of new statute in accordance with the demand of society by inserting scope under the Directive Principles of State Policies. However, in the 67 years history of Indian Republic, there are unprecedented developments of law relating to factories in India.

The Government of India, with the adoption of existed statute, made an effort to incorporate the welfare legislation but it never developed along with the change in time. It is to be noticed that as far as existing statutes are concerned, the development is an effect of judicial pronouncement or some tragic incident like Bhopal Gas Tragedy. This paper succinctly describes the history of factory legislation, the constitutional validity of the previous statute and necessary amendment which have already been done and/ or on the verge of being amended. It will further discuss contribution of judiciary in developing the law relating to factories, scope of industrial jurisprudence in promoting the development of factory legislation. The primary focus of the research project is to reflect upon the areas where factory legislation has developed, so that proper yardstick could be made in order to put emphasis on those areas which have been remained untouched.

Keywords: factory; development; contribution; jurisprudence; legislation.

Recommended citation: Manjeet Kumar Sahu, Development of Law Relating to Factories in India, 2(2) BRICS LJ (2015). 


\section{Table of Contents}

\section{Introduction}

2. Origin of Factory Legislation

3. Scope of Industrial Jurisprudence in Developing Factory Legislation

3.1. Concept of Social Welfare Legislation: Derivative of Indian Constitution

\subsection{Jurist Opinion}

4. Development of Factory Legislation

4.1. Legislative Development

4.2. Judicial Development

4.3. International and Regional Conventions

5. Areas to Be Developed under Factory Legislation

5.1. Social Security of Workers (emphasis on female workers)

5.2. Safety Measures

\subsection{Health and Hygienic Conditions}

\subsection{Proper Infrastructure}

\subsection{Remedies}

5.5.1. Periodical Review of the Inadequacy of Existing Legislation

5.5.2. Preventive Measure

5.5.3. Effective Steps for Identification of Occupational Diseases

5.5.4. Revision of the List of Occupational Diseases

\section{Conclusion}

\section{Introduction}

Nothing in this world remains stationary, the only constant is change. Law is a dynamic subject. The developments of law relating to factories in India trace its origin from factories legislation of United Kingdom. The movement for the regulation of factories was the outcome of a new attitude of mind towards industrial questions. The application and industrial jurisprudence of UK legislations provided skeletal in order to shape the factories legislation in India.

The rapid growth of industrial town and factories has paved the way to develop our industrial legislation accordingly. The Government of India never expressed their interest in framing separate legislation vis-à-vis factories which resulted in implementation of the same statute which was enacted pre-independence. It was done by virtue of Art. 372 of the Constitution of India. However, the Constitutional Lawmakers created vacuum for the implementation of new statute in accordance with the demand of society by inserting scope under the Directive Principles of State Policies. However, in the 65 years history of Indian republic, there are unprecedented developments of law relating to factories in India. 
The primary objective of the factory legislation in India is as follows:

1) to hinder the diversion of the nation's industry into such unprofitable channels;

2) to maintain a healthy minimum in the standard of life;

3) to prevent any person being employed under conditions inimical to social health;

4) to prescribe conditions of existence below which population shall not decline.

\section{Origin of Factory Legislation}

It will be remembered that the Elizabethan Poor Law of 1601 had directed that destitute children and orphans should be apprenticed to some trade. Houses of industry for instructing these children in spinning and weaving were a favorite charitable hobby in the $17^{\text {th }}$ and $18^{\text {th }}$ centuries, and the children were subsequently bound apprentice to employers. There is a considerable literature on this subject, sometimes giving a roseate description of the interiors of these industrial schools which does not always convey to the modern reader an impression as favorable as the writer intended.'

Later, the Factory Act of 1802 may be regarded rather as an extension of the old Poor Law ${ }^{2}$ than as the conscious assumption of control over industry, ${ }^{3}$ The year 1802 is marked by the passing of the first of long series of structures regulating the hours and conditions of labour, commonly known as the Factory Acts. These acts have been framed with the definite and avowed object of protecting the health of the younger and weaker workers from injury by overwork or unwholesome conditions and it is this, their motive and purpose, rather than the actual matter of the regulation, that forms their distinguishing characteristic and marks them out as a novelty and new departure from previous legislation. There is little or no analogy between these and the medieval labour statutes or the ordinance of the craft guilds. ${ }^{4}$

Although Bengal must be credited with the first cotton mill opened about the year 1818. It was not till the second half of $19^{\text {th }}$ century that the introduction of power spinning and weaving made any progress. In Bombay, the first mill was established in 1851. By 1879-80 (the first year for which complete authentic official records are available), there were 58 cotton spinning and weaving mills in India with an aggregate of 13,307 looms and 1,470,830 spindles and a daily average employment of 39,537 persons. The first jute mill was started in 1855, the first power loom being

B.L. Hutchins \& A. Harrison, A History of Factory Legislation 2-3 ( $2^{\text {nd }}$ ed., P.S. King \& Son 1911), available at <https://archive.org/details/ahistoryfactory01 spengoog > (accessed Feb. 5, 2016).

2 The Health and Moral of Apprentices Bill introduced in the Parliament was passed without any difficulty and was regarded as poor law.

3 J.C. Kydd, A History of Factory Legislation in India (Calcutta University Press 1920), available at <https:// archive.org/details/historyoffactory00kydduoft> (accessed Feb. 5, 2016).

4 Hutchins \& Harrison, supra n. 1, at 3. 
introduced in 1859. Though at first progress was slow, by the year 1879-80, 22 jute mills existed in India with 4,946 looms and 70,840 spindles and employing an average of 27,494 persons daily. It was the growth of the cotton industry in Bombay, however, which at first chiefly attracted attention. ${ }^{5}$

The period of this early expansion in India was a time in the United Kingdom when interest in the whole question of factory legislation was considerable. In the early part of $1873 \mathrm{Dr}$. Bridges and Mr. Holmes conducted an enquiry at the instance of the Local Government Board into the health of women, children and young persons engaged in textile manufacture. The last act dealing with this matter was that of 1847 and they recommended a review of the situation considering 10.5 hours of monotonous, unceasing labour, even under favorable conditions, as too long to be consistent with the health of young persons between 13 and 18 years of age and of women generally. They urged in consequence, a reduction of the working week from 60 to 54 hours. ${ }^{6}$

In 1874, under the Conservative Government which came into power in that year was passed the act thus entitled 'An Act to Make Better Provision for Improving the Health of Women, Young Persons and Children Employed in Manufactures and the Education of Such Children and Otherwise to Improve the Factory Acts.'

It can be noticed that the Factory Acts did not deal with industry as a whole. Legislation had been gradually extending from industry to industry and as a result certain elements of inequality and unnecessary complexity existed in the body of the Factory Laws.' In consequence of the realization, a committee was appointed in 1875 to inquire into the conditions of factory work in the country. This committee had favored some kind of legal restrictions in the form of factory laws.

During Lord Ripon;s time, the first Factories Act was adopted in 1881. This enactment primarily focused on children: ${ }^{8}$

1) that no child should be employed in factory if under the age of 7 years;

2) that no person under the age of 12 years, should be actually employed in any factory more than nine hours in any one day;

3) that every child was to have four whole holidays in the month;

4) that children were not to be employed in certain dangerous work.

Following this act, a Factory Commission was appointed in 1885. There was another Factories Act in 1891, and a Royal Commission on Labor was appointed in 1892. The result of these enactments was the limitation on the factory working hours. This was an answer of the Government to the pathetic conditions of the

\footnotetext{
Kydd, supra n. 3, at 12.

ld.

Id.

8 D.A. Barker, Factory Legislation in India, 21(84) The Economic Journal 643 (1911).
} 
workers in the factory, wherein, only when a laborer exhausted, new labourer was to take his / her place.'

The legislation was projected as the panacea for all the ills that plagued factory and industrial administration in India. It limited endless working hours, stipulated the minimum ages of those to be employed, and tried to ensure that there would be some gubernatorial safeguard in place for the conditions of the workers in factories. It was designed to protect children ${ }^{10}$ and provide measures for the health and safety of the workers."

In India various committees and commissions were appointed from time to time by the Government of India to inquire into the problems of health of industrial workers. In 1929 the Royal Commission on Labor noted that in a number of factories due to manufacturing processes a large amount of dust is deposited and that arrangements for its elimination were mostly defective. In October 1943 the Government of India appointed Health Survey and Development Committee to consider and suggest broad objectives of health and medical care in the country. Later, the Labor Investigation Committee set up under the Chairmanship of Shri D.D. Rege by the Government of India emphasized in its report, submitted in 1946, the responsibility of the employer to provide for medical and health facilities.

With the high speed growth of various industries in India, regulation became necessary and hence, accordingly fashioned all the factories legislation of United Kingdom with suitable modification.

\section{Scope of Industrial Jurisprudence in Developing Factory Legislation}

Jurisprudence teaches legislators how to make laws which will promote social and economic welfare. ${ }^{12}$ The primary concern of industrial jurisprudence is to maintain peace among the various parties and ensure the contentment of the workers. Both jurisprudence and economics aim at the betterment of the lives of the people. There are laws relating to workmen's compensation, factory legislation, laws relating to labour, insurance, maternity welfare, bonus, leave facilities and other concessions given to workmen. There are laws for the benefits of the agriculturists such as the Zamindari Abolition Acts, Agricultural Debtors Relief Acts, Acts preventing the fragmentation and sub-division of agricultural holdings and regulation of agricultural

9 <http://www.gktoday.in> (accessed Feb. 5, 2016).

10 Barker, supra n. 8.

11 Kirthi Jayakumar, The First Labour Statute, myLaw (May 4, 2012), <http://version1.mylaw.net/index. php/Article/The_first_labour_statute/> (accessed Feb. 5, 2016).

12 Lellala Vishwanadham, Jurisprudence in Relations with Other Social Sciences, 3(5) VSRD Technical \& Non-Technical Journal (2012). 
labour. Both jurisprudence and economics help each other in furthering the welfare of society. The intimate relation between economics and jurisprudence was first emphasized by Karl Marx. ${ }^{13}$

\subsection{Concept of Social Welfare Legislation: Derivative of Indian Constitution}

The principle of International Labour Organization [hereinafter ILO] have already been incorporated under the Constitution of India. ${ }^{14}$ The Constitution of India in its Preamble provided a framework for securing to all its citizens, inter alia, social justice which has been amplified and elaborated in Pt. IV of the Constitution 'Directive Principles of State Policy.'

These Directive Principles provide for securing the health and strength of employees, men and women, ${ }^{15}$ that the tender age of children are not abused, that citizens are not forced by economic necessity to enter avocations unsuited to their age or strength, ${ }^{16}$ just and humane conditions of work and maternity relief are provided, ${ }^{17}$ that the Government shall take steps, by suitable legislation or in any other way, to secure the participation of employee in the management of undertakings, establishments or other organizations engaged in any industry, ${ }_{1}^{18}$ for ensuring that no child below the age of 14 is employed to work in any factory or mine or engaged in any other hazardous employment. ${ }^{19}$

\subsection{Jurist Opinion}

The development of labour law remains in a large part in the period when industrial production was introduced. The formation and development of factory legislation is regarded as the seed of the creation of labour law. Several authors have though claimed that the legal regulation of labour relations does not originate solely from the development of factory legislation but the modern labour law has several connections with Roman private law and the modern employment contract has, in fact, evolved as a result of the classification of contracts found in Roman law. ${ }^{20}$

13 Dennis Lloyd, Introduction to Jurisprudence ( $4^{\text {th }}$ ed., Stevens \& Sons 1979).

14 Article 39.

15 Fifth India-EU Seminar on Employment and Social Policy 'Occupational Safety and Health' (New DelhiSeptember 19-20, 2011), <http://labour.nic.in/upload/uploadfiles/files/Divisions/LC\%26ILAS/ Background\%20note.pdf> (accessed Feb. 5, 2016) [hereinafter Fifth India-EU Seminar].

16 Supran. 14.

17 Constitution of India, Art. 42.

18 Id. Art. 43A.

19 Id. Art. 24.

20 Gaabriel Tavits, The Position of Labour Law in the Private Law System. The Past, Present and Future of Estonian Labour Law, 5(1) Juridica International (2000), available at <http://www.juridicainternational. eu/public/pdf/ji_2000_1_124.pdf> (accessed Feb. 5, 2016). 
Robert Owen's idea of fixing a 'national minimum' in the standard of life, below which, in the common interest, no one is to be permitted to sink. ${ }^{21}$

Dr. Thomas Bedford in his report 'The Health of the Industrial Worker in India' (1946) drew the attention of the authorities, inter alia, to the inadequacy of protection given to Indian factory workers from dangerous dusts and to the importance of keeping a careful watch on industries in which organic solvents and radioactive materials were used. ${ }^{22}$

\section{Development of Factory Legislation}

\subsection{Legislative Development}

Regulation of employment contract and labour relations under law of obligations or outside it is not a legal and political decision. Rather, it is a question of legislative technique. ${ }^{23}$

Early Legislations:

1) the First Indian Factory Act, 1881;

2) the Bombay Factory Commission of 1884-85;

3) interest in Indian factory labour in the United Kingdom; the Indian Factory Commission of 1890 and the Act of 1891;

4) controversy between trade rivals; night work; the Textile Factories Labour Committee of 1906;

5) the Indian Factory Labour Commission of 1908 and the Act of 1911.

The original colonial legislation underwent substantial modifications in the postcolonial era because independent India called for a clear partnership between labour and capital. The earliest Indian statute to regulate the relationship between employer and his workmen was the Trade Dispute Act, 1929 (Act VII of 1929). Provisions were made in this act for restraining the rights of strike and lock out but no machinery was provided to take care of disputes.

The legislations can be categorized as follows:

1) labour laws enacted by the Central Government, where the Central Government has the sole responsibility for enforcement;

2) labour laws enacted by Central Government and enforced both by Central and State Governments;

3) labour laws enacted by Central Government and enforced by the State Governments;

4) labour laws enacted and enforced by the various State Governments which apply to respective States.

21 Hutchins \& Harrison, supra n. 1.

22 N.S. Nankiker, Working Conditions in Factories Referred in Government of India: The Conference of Chief Inspectors of Factories Held at New Delhi 26 (1968).

23 Tavits, supra n. 20. 


\subsection{Judicial Development}

At present one must admit that labour law is increasingly treated as judicial matter. ${ }^{24}$ While delineating the scope of constitutional provisions, Justice K. Ramaswamy in his dissenting judgement in Calcutta Electricity Supply Corp. v. Subhas Chandra Bose \& Ors. ${ }^{25}$ observed that health is a human right enshrined in the Universal Declaration of Human Rights (Arts. 22-28) and International Covenant on Economic Social and Cultural Rights. Further, it is a fundamental right to workmen. The 'maintenance of health is a most important constitutional goal.' Health does not mean 'the absence of disease or infirmity' but'a state of complete physical, mental and social well-being.'

In Consumer Education \& Research Centre \& Ors. v. Union of India \& Ors. ${ }^{26}$ a threejudge bench of the Supreme Court held that the jurisprudence of personhood or philosophy of the right to life envisaged in Art. 21 of the Constitution enlarges its sweep to encompass human personality in its full blossom with invigorated health which is a wealth to the workman to earn his livelihood, to sustain the dignity of person and to live a life with dignity and equality. The expression 'life' assured in Art. 21 does not connote mere animal existence or continued drudgery through life. It has a much wider meaning which includes right to livelihood, better standard of living, hygienic conditions in the workplace and leisure facilities and opportunities to eliminate sickness and physical disability of the workmen. The health of the worker is an integral facet of the right to life. Denial thereof denudes the workman the finer facets of life violating Art. 21. Medical facilities, therefore, is a fundamental and human right to protect his health. In that case health insurance, while in service or after retirement was held to be a fundamental right and even private industries were enjoined to provide health insurance to the workmen. In this case the Supreme Court observed that in the light of the rules '[a]ll safety in the use of asbestos' issued by the ILO, the same shall be binding on all the industries.

The aforesaid view was reiterated in Kirloskar Brothers Ltd. v. Employees' State Insurance Corp. ${ }^{27}$ The Court observed that in expanding economic activity in a liberalized economy Pt. IV of the Constitution enjoins not only the State and its instrumentalities but even private industries to ensure safety to the workman and to provide facilities and opportunities for health and vigor of the workman assured in relevant provisions in Pt. IV which are integral part of the right to equality under Art. 14 and the right to life under Art. 21 which are fundamental rights to the workman.

The Court has also directed all the industries large, medium, small, mines milling units, etc. to cover their workers by health insurance. ${ }^{28}$

24 Tavits, supra n. 20

25 (1992) 1 S.C.C. 441

26 (1995) 3 S.C.C. 42.

271996 S.C.C. (L\&S) 533.

28 S.C. Srivastava, Occupational Health of Workers in India Law and Practice, 31 Ban. L.J. 11, 18 (2002), available at <http://www.bhu.ac.in/lawfaculty/bljvol31.html > (accessed Feb. 5, 2016). 
The Supreme Court in M.C. Mehta v. Union of India (December 20, 1986) ${ }^{29}$ evolved a new concept of liability to deal with problems of hazardous and inherently dangerous industries. The court held that an enterprise which is engaged in a hazardous or inherently dangerous industry which poses a potential threat to the heath and safety of the persons working in the factory and residing in the surrounding areas owes an absolute and non-delegable duty to the community to ensure that no harm results to anyone on account of hazardous or inherently dangerous nature of the activity which it has under taken. The enterprise engaged in such nature of activity should indemnify all those who suffer on account of the carrying on of such activity regardless of whether it is carried on carefully or not. ${ }^{30}$

The Supreme Court in M.C. Mehta \& Anor. v. Union of India \& Ors. (February 17, $1986)^{31}$, where tanneries were discharging effluents into the river Ganges prevented the tanneries etc., from discharging effluents into the river Ganga, directed establishment of primary treatment plats etc., and ordered the closure of industries not complying with the directions $s^{32}$.

In Rural Litigation and Entitlement Kendra v. State of Uttar Pradesh, ${ }_{13}^{33}$ a large scale pollution was caused by lime stone quarries adversely affecting the safety and health of the people living in the area. On the suggestions of the Committee appointed by the Supreme Court, the Court ordered the closure of certain lime stone quarries ${ }^{34}$.

In Municipal Corp. of Delhi v. Female Workers (Muster Roll) \& Anor. ${ }^{35}$ it was declared that the maternity benefit is applicable to casual workers and daily wage workers also.

Moreover, in plethora of judgments, ${ }^{36}$ the Supreme Court have endeavored to enforce equal pay for equal work which is also enshrined under the Indian Constitution. The judicial encroachment in the form of judicial activism in order to fill the gap and lend the ears to the public have greatly helped in the development of the factory legislation. The cat of judiciary as a watchdog of the executive and legislature is truly commendable.

29 A.I.R. 1987 S.C. 1086.

30 Application of Polluter Pays Principle.

31 A.I.R. 1987 S.C. 965.

32 Application of Precautionary Principle.

33 A.I.R. 1988 S.C. 2187.

34 Application of Precautionary Principle.

35 A.I.R. 2000 S.C. 1274.

36 Peoples Union for Democratic Rights v. Union of India, 1982 Lab. IC 1646, 1658; Randhir Singh v. Union of India, A.I.R. 1982 S.C. 879; Sanjit Roy v. State of Rajasthan, A.I.R. 1988 S.C. 328; Food Corp. of India v. Shymal K. Chatterjee, 2000 L.L.R. 1293 (S.C.); Mackinnon Mackenzie \& Co. Ltd. v. Audrey D'Costa \& Anor., A.I.R. 1987 S.C. 1281; S. Nagaraj \& Ors. v. State of Karnataka \& Anor., (1993) Supp. (4) S.C.C. 595, 620; Vijay Kumar \& Ors. v. State of Punjab \& Ors., A.I.R. 1994 S.C. 265; State of West Bengal \& Ors. v. Pantha Chatterjee \& Ors., A.I.R. 2003 S.C. 3569; Union of India v. T.R. Das, A.I.R. 2004 S.C. 852. 


\subsection{International and Regional Conventions}

Most of the factory legislations in India have been inspired either by the international conventions or the regional conventions. Some traces of all these conventions can be easily traced in the Indian legislation. Contribution of such valuable inputs around the globe cannot be ignored.

Article 5(2) the Asbestos Convention, 1986, requires that the '[n]ational laws or regulations shall provide for the necessary measures, including appropriate penalties, to ensure effective enforcement of and compliance with the provisions of this Convention.'

Article 8 obliges '[e]mployers and workers or their representatives [to] co-operate as closely as possible at all levels in the undertaking in the application of the measures prescribed pursuant to this Convention.'

The inspector is empowered to take sufficient sample of any substance used or intended to be used in the factory, which in his opinion is likely to cause bodily injury to, or injury to the health of, workers in the factory. ${ }^{37}$ This provision has been inserted to give effect to Art. 12 of the Labour Inspection Convention, 1947. The Maternity Protection Conference in 1919 set out the scope for the Maternity Benefits Act, 1961.

The concern felt by the ILO for providing medical and health care resulted in several ILO conventions and recommendations. As early as in 1927 the ILO adopted Convention No. 25 concerning sickness insurance and Recommendation No. 29 relating to general principles on sickness insurance. Further, in 1944 the Philadelphia Convention adopted Recommendation No. 69 which laid down norms of medical care. Again, in June 1953, the ILO adopted Recommendation No. 97 concerning the protection of health of workers in places of employment. The Recommendation laid down that employment for occupations involving special risk to the health of workers should be on the condition that (i) medical examination is carried out shortly before or after a worker enters employment, and (ii) periodical medical examination is done after he has joined the employment. In 1959, the ILO adopted another recommendation concerning occupational health services. The Recommendation envisages that'occupational health services' should be established in or near a place of employment for (i) protecting the workers against any health hazard arising from work or conditions in which work is carried on, (ii) contributing towards the workers' physical and mental adjustment, and (iii) contributing to establishment and maintenance of the highest possible degree of physical and mental well-being of workers.

Time and again, the ILO has expressed its concern about increased hazards from radiation processes, as a result of fast changes in industrial technology. Thus, in June 1960, it adopted Recommendation No. 114 and Convention No. 115 concerning the protection of workers against ionizing radiation. The same year witnessed the

\footnotetext{
37 Factories Act, 1948, Sec. 91.
} 
passing of the Radiation Protection Convention, $1960 .{ }^{38}$ This was followed by several other important conventions such as Benzene Convention, 1971, ${ }^{39}$ Occupational Cancer Convention, 1974, ${ }^{40}$ Working Environment (Air Pollution, Noise and Vibration) Convention, 1977, ${ }^{41}$ and Occupational Safety and Health (Dock Work) Convention, 1979. ${ }^{42}$ The ILO being alive to the problems of enforcement set standards by adopting Occupational Safety and Health Convention, 1981, providing for the enforcement of law and regulation concerning occupational health and requiring adequate and appropriate inspection machinery. Despite the existence of aforesaid ILO conventions and recommendations, the problems of occupational health of workers continues and commissions to cause concern.

The role of the World Health Organization [hereinafter WHO] in order to improve the condition of the work place has also helped immensely in developing the factory legislation in India. In 1973, WHO defined the Scope and Extent of Occupational Health Programmes to identify and bring under control at the workplace all chemical, physical, mechanical, biological and psychological agents that are known to be or suspected to be hazardous and to discover and improve work situations that may contribute to the ill health of workers in order to ensure that burden of general illness in different occupational groups is not increased over the community level. ${ }^{43}$

\section{Areas to Be Developed under Factory Legislation}

The legislative as well as the administrative action is truly commendable in order to satisfy all the need of labour industry. Their contribution in order to uplift the industry and provide clean environment for the workers could be noticed through the recent development and amendment in Indian laws. However, there are still certain areas that need to be developed under factory legislation.

\subsection{Social Security of Workers (emphasis on female workers)}

Even after 25 years, WHO programmes have benefited only a minuscule of women workers in developing countries. Approximately 2.5 billion persons work worldwide and only 15 percent of the workforce live in what may be called as rich or high income countries. The pattern of employment in different countries is vastly

38 Article 12.

39 Articles 9 and 10.

40 Article 5.

41 Article 11.

42 Article 36.

43 Aruna Dewan, Occupational and Environmental Health of Women, <http://www.un.org/womenwatch/ daw/csw/occupational.htm> (Feb. 6, 2016). 
different. ${ }^{44}$ In India unlike USA there is no statute providing protection to women from reproductive hazards in the work place..$^{45}$ One of the primary objective of factory legislations are to enable the women to enjoy equally as men a fuller and richer life, to increase their efficiency, to increase their participation in useful services to ensure their antenatal, prenatal care and infant welfare and to provide equal pay for equal work. ${ }^{46}$

They work under extreme climatic conditions and the nature of their heavy manual work often results in miscarriages or restarted foetal growth. A large number of women work in the tobacco processing industry. Besides the usual chest diseases, it is suspected that tobacco dust is affecting the menstrual cycle of women and lactation in young mothers. The extensive use of pesticides in cotton growing areas has resulted in, amongst other afflictions, stunted growth of farm workers' children. ${ }^{47}$ Occupational health problems of women are a major thrust area for the institute and the country. A number of such occupations have been identified and studies have been initiated in collaboration with the Self Employed Women's Association (SEWA). Examples are Agarbatti workers (incense stick makers), salt workers, scrap cleaners, screen printing workers and agricultural labourers exposed to pesticides. ${ }^{48}$

In Wright v. Olin Corp. ${ }^{49}$, the court characterized foetal protection as a valid business concern. In Hayes v. Shelby Memorial Hosp. ${ }^{50}$ the court held that firing of an employee because she is pregnant is discriminatory under the Pregnancy Discrimination Act.

Judiciary has played a significant role in protecting the interests of the female. In B. Shah v. Presiding Officer, Labour Court, Coimbatore \& Ors. ${ }^{51}$ the Supreme Court pointed out:

Performance of the biological role of the childbearing necessarily involves withdrawal of a women from the workforce for some period and she cannot

44 Dewan, supra n. 43.

45 Srivastava, supra n. 28 , at 38.

46 See C.B. Mamoria \& Satish Mamoria, Industrial Labour, Social Security and Industrial Peace in India 136 (Kitab Mahal 1984); Renu Jamwal \& Deepti Gupta, Work Participation of Females and Emerging Labour Laws in India, 2(1) Asia-Pacific Journal of Social Sciences (2010), available at <https://www. researchgate.net/publication/265925959_Work_Participation_of_Females_and_Emerging_Labour_ Laws_in_India> (accessed Feb. 6, 2016).

47 Anil Agarwal \& Sunita Narain, The State of India's Environment, 1984-85: The Second Citizens Report 247 (Centre for Science and Environment 1985).

48 Dewan, supra n. 43.

49697 F.2d 1172 (1982).

50726 F.2d 1543 (11th Cir. 1984).

51 (1977) 4 S.C.C. 384. 
work for her medical expenses also. In order to enable the woman worker to subsist during this period and to preserve her health, the law makes a provision for maternity benefit so that the women can play both her productive and reproductive roles efficiently.

\subsection{Safety Measures}

Increasing number of accidents involving workers has drawn our attention towards safety measures in the factories. Accidents not only affect workers loosing their livelihood but also employers in terms of compensation to be paid to the workers. Accidents are a significant cause of dispute between workers and management. ${ }^{52}$ The Factories Act, 1948, has laid down certain measures for the safety of workers employed in the factories.

In accordance with the specific provisions for ensuring occupational safety and health for working population in the Constitution of India, several legislations have been framed dealing with the safely, health and welfare of the workers employed in the organized sector. ${ }^{53}$

On the basis of these Directive Principles and international instruments, the Government of India declares its policy, priorities, strategies and purposes through the exercise of its power. The Government is committed to regulate all economic activities within the country with a view to ensuring that every working employee is provided with safe and healthful working conditions. Accordingly, Government of India enacted the statutes relating to occupational safety and health at workplaces namely: the Mines Act, 1952, and rules and regulations framed thereunder; the Factories Act, 1948, and Rules framed thereunder; Dock Workers (Safety, Health and Welfare) Act, 1986, and regulations and rules framed thereunder; the Building and Other Construction Workers (Regulation of Employment and Conditions of Service) Act, 1996, and rules framed thereunder; the Dangerous Machines (Regulation) Act, 1983, and rules framed thereunder; the Insecticides Act, 1968, and rules framed thereunder; the shops and establishments acts of State Governments; the Beedi and Cigar Workers' (Conditions of Employment) Act, 1966; the Municipal Solid Waste (Management and Handling) Rules, 2000, notified under the Environment (Protection) Act, 1986; the Manufacture, Storage \& Import of Hazardous Chemicals Rules, 1989; the Electricity Act, 2003; etc. These are some of the important statutes covering occupational safety and health aspects of workers. ${ }^{54}$

52 Safety Measures in Factories, <http://download.nos.org/srsec319/319-39.pdf> (accessed Feb. 6, 2016).

53 Report of the Working Group on Occupational Safety and Health for the Twelfth Five Year Plan (2012 to 2017), Government of India, Ministry of Labour and Employment (August 2011), at <http:// planningcommission.nic.in/aboutus/committee/wrkgrp12/wg_occup_safety.pdf $>$ (accessed Feb. 6, 2016) [hereinafter Report].

${ }^{54}$ Id. ๆ 1.3. 


\subsection{Health and Hygienic Conditions}

'The Ministry of Labour \& Employment, Govt. of India \& Labour Departments of the States and Union Territories are responsible for the safety \& health of the workers. ${ }^{155}$ The modernization and innovation in industries and rapid increase in chemical, hazardous, and polluting industries in recent years has not only resulted in unsafe working conditions but has created problems of occupational health hazards. ${ }^{56}$ Work related hazards is changing with the introduction of new chemical substances which pose a threat to community and workers alike. ${ }^{57}$ It is, therefore, essential to take effective measures to protect the workers from such risks and dangers.

The following measures needs to be implemented in the work places to enhance occupational health: ${ }^{58}$

- identify and involve workers in assessing workplace risks;

- assess and consider employees' needs when planning and organizing work;

- provide advice, information and training to employees, as well as mechanisms for employee feedback such as a suggestion scheme;

- occupational health surveillance and occupational health audit;

- to develop a system of creating up to date data base on mortality and morbidity due to occupational diseases especially those occurring due to asbestos and silica exposure in these categories of workers and use it for performance monitoring of the same;

- extending support to the state government for effective enforcement of the health provisions stipulated under Sec. $41 \mathrm{~F}$ of the Factory Act by equipping them with work environment monitoring technologies.

It is essential that promoting occupational health at work places should be resorted and the following are the benefits of such measures: ${ }^{59}$

- injury and illness prevention;

- enhanced occupational health of the workers;

- reduction in occupational illness and diseases;

- legal compliance;

- lower absenteeism;

- improved relationships with customers and suppliers;

- improved productivity;

- reduced staff turnover;

- sensitization of stake holders to adopt low cost dust control appliances to ensure safety and health protection of weaker sections especially migrant workers in dusty trades;

\footnotetext{
55 Report, supra n. 53.

56 Srivastava, supra n. 28, at 11.

57 Id.

58 Fifth India-EU Seminar, supra n. 15, at 29.

59 Id. at 30.
} 
- technical assistance to state health department to set up diagnostic centres of international standards and evolve a system of periodic health surveillance of such workers on a regular basis;

- generate adequate numbers of Associate Fellow of Industrial Health [hereinafter $\mathrm{AFIH}$ ] qualified doctors through increasing the number of accredited medical colleges to start AFIH courses to maintain the supply chain of qualified medical officers competent to tackle the problems;

- the deliverables like standards, codes of practices, guidelines, posters, and films on key occupational health issues are generated and utilized as tools for raising awareness levels of key stake holders for promoting safety and health standards of the vulnerable groups of workers.

\subsection{Proper Infrastructure}

The need for further development in factory legislation in India is an open one, no doubt exists either in the minds of the employees of labour or in the minds of the informed public of the importance of improving the general conditions under which factory lives. ${ }^{60}$ It is to be noted that the rooms on the ground floor are often pitch dark and possess very little in the way of windows. The question of housing for workers are still acute which could be remedied through better transport services

\subsection{Remedies}

The National Commission on Labour has laid considerable emphasis on continuous study of new problems with a view to suggesting remedies to suit the changing environment and to avoid health hazards. ${ }^{61}$ The institutions of governance at grass root can monitor the policies, programmes and laws to ensure protection of labour interests and rights. Gram Panchayat can play a responsible role in identification of the projects in the Gram Panchayat areas and allocate employment opportunities to the needy.

The rehabilitation of a worker disabled should be one the most beneficial objectives of the Workmen's Compensation Act, 1923, or the Employees' State Insurance Act, 1948. If the disabled worker can be rehabilitated and returned to useful productive capacity, the cost saving in future benefits can move. This is also desirable from social view point. However, this benefit has not so far been provided under the labour legislation particularly in the Workmen's Compensation Act, 1923, or the Employees'State Insurance Act, 1948. In the absence of any legislative nor, the Supreme Court played a creative role to protect the interest of workers for premature incapacitation to do the required work due to occupational disability. Thus in Anand Bihari v. Rajasthan State Road Transport Corp., Jaipur ${ }^{62}$ the Court, inter alia, was called

\footnotetext{
60 Kydd, supra n. 3.

${ }^{61}$ Srivastava, supra n. 28, at 11.

62 (1991) Lab. I.C. 494.
} 
upon to decide whether the order of termination of service of drivers (over 40 years of age) for developing weak or sub-normal eyesight or losing required vision on account of their occupation as drivers of the corporation was proper, equitable and just. If not what should be done?

Some of the direction that can be given to the legislative and administrative actions are as follows.

\subsubsection{Periodical Review of the Inadequacy of Existing Legislation}

One of the main reason for dissatisfaction with legislation is that it accommodates multiple proceedings and different statutes for different industries. It is, therefore, a need to periodically review the growth of industries in the covered area and the inadequacy of existing facilities as suggested by the Planning Commission report and the Law Commission report.

\subsubsection{Preventive Measure}

There is a need to shift the emphasis to prevention of occupational diseases. The most important and effective means of prevention of diseases is periodical medical check up. All the workers covered over the Employees' State Insurance Act, 1948, and the Workmen's Compensation Act, 1923, on their entry into regular services should be required to undergo a medical check up and thereafter at least once in three years. This should be done particularly in those cases where workers are liable to contract occupational diseases.

\subsubsection{Effective Steps for Identification of Occupational Diseases}

There is a need to take more effective steps for proper identification of occupational diseases in each industry.

\subsubsection{Revision of the List of Occupational Diseases}

The current list of occupation diseases given in the Third Schedule of the Employees'State Insurance Act, 1948, and the Factories Act, 1948, and the Workmen's Compensation Act, 1923, should as far as possible be uniform and the list of diseases should be reviewed and revised in the light of the list of occupational diseases laid down in the current ILO Convention on the subject taking into account the nature of industries and occupations prevalent in the country. The government / corporation has already got power to add new diseases to the schedule.

\section{Conclusion}

Unless there are socially conscious policies in the country, the policies won't make that much of a difference. It is still true that things are not very good for labour. Labour rights need to be actively respected rather than simply acknowledged and 
we must admit that more than the passage of laws and publicizing the same to stimulate the kind of debate in such a way that leads to attitudinal change.

There is need to create community monitoring system through their effective participation in the Gram Sabha and other local bodies. Strengthening community participation in the whole process by way of conducting regular social audits of all the programmes is a prerequisite.

There are comprehensive safety and health statutes for regulating safety and health of persons at work exists but the approach in statutes is to lay down specific and detailed requirements to prevent risk of injuries in specific operations or circumstances. This lacks uniformity and a well-coordinated approach to safety and health in all sectors of the economy. There is a strong need for a general (umbrella) legislation covering safety and health aspects of workers employed in all sectors of economy irrespective of the number of employees employed in those units. ${ }^{63}$

The gravity of situation may be gauged from the observation made in 1992 by Justice Ramaswamy that 'in three minutes somewhere in the world one worker dies and in every second that passes at least three workers are injured,' and in India 'on average every day 1,100 workers are injured and three are killed. ${ }^{\prime 4}$

\section{References}

Agarwal, Anil, \& Narain, Sunita. The State of India's Environment, 1984-85: The Second Citizens Report 247 (Centre for Science and Environment 1985).

Barker, D.A. Factory Legislation in India, 21(84) The Economic Journal 643 (1911).

Dewan, Aruna. Occupational and Environmental Health of Women, <http://www. un.org/womenwatch/daw/csw/occupational.htm> (Feb. 6, 2016).

Hutchins, B.L., \& Harrison, A. A History of Factory Legislation 2-3 ( $2^{\text {nd }}$ ed., P.S. King \& Son 1911), available at <https://archive.org/details/ahistoryfactory01spengoog $>$ (accessed Feb. 5, 2016).

Jamwal, Renu, \& Gupta, Deepti. Work Participation of Females and Emerging Labour Laws in India, 2(1) Asia-Pacific Journal of Social Sciences (2010), available at <https:// www.researchgate.net/publication/265925959_Work_Participation_of_Females_ and_Emerging_Labour_Laws_in_India> (accessed Feb. 6, 2016).

Jayakumar, Kirthi. The First Labour Statute, myLaw (May 4, 2012), <http://version1. mylaw.net/index.php/Article/The_first_labour_statute/> (accessed Feb. 5, 2016).

Kydd, J.C. A History of Factory Legislation in India 12 (Calcutta University Press 1920), available at <https://archive.org/details/historyoffactory00kydduoft> (accessed Feb. 5, 2016).

\footnotetext{
63 Report, supra n. 53, ๆ 1.12.

64 Srivastava, supra n. 28, at 11.
} 
Lloyd, Dennis. Introduction to Jurisprudence ( $4^{\text {th }}$ ed., Stevens \& Sons 1979 ).

Mamoria, C.B., \& Mamoria, Satish. Industrial Labour, Social Security and Industrial Peace in India 136 (Kitab Mahal 1984).

Srivastava, S.C. Occupational Health of Workers in India Law and Practice, 31 Ban. L.J. 11, 18, 38 (2002), available at <http://www.bhu.ac.in/lawfaculty/bljvol31.html> (accessed Feb. 5, 2016).

Tavits, Gaabriel. The Position of Labour Law in the Private Law System. The Past, Present and Future of Estonian Labour Law, 5(1) Juridica International (2000), available at <http://www.juridicainternational.eu/public/pdf/ji_2000_1_124.pdf> (accessed Feb. 5, 2016).

Vishwanadham, Lellala. Jurisprudence in Relations with Other Social Sciences, 3(5) VSRD Technical \& Non-Technical Journal (2012).

\section{Information about the author}

Manjeet Kumar Sahu (Ranchi, India) - LL.M. (Constitutional and Administrative Law) Student at National University of Study and Research in Law (Ranchi, India) (Ward No. 11, Shanti Nagar, Palkot Road, Gumla, 835207, Jharkhand, India; e-mail: manjeetsahu2009@gmail.com). 